\title{
CORONA ECONOMIC CRISIS: IMPLICATIONS AND LESSONS
}

\section{Annotation}

The purpose of our study is to reveal the essence and root causes of the current corona-economic crisis, both in terms of the damage caused and the impact on national economies and the world economy, and from the standpoint of its perception by humans, society and authoritative organizations of regional and global importance. In addition to analyzing the main trends and phenomena associated with the pandemic, the task is to study the social and economic consequences, assess the effectiveness of policies to reduce the negative impact of states and substantiate the need for all countries to be ready for multilateral and mono-sided cooperation in all areas of public activity. Numerous lessons that need to be learned from the current situation in order to work out a strategy for the development of mankind and individual states, as well as to avoid the repetition of possible mistakes and failures in the future, seem vital. Finally, an attempt is made to predict the state of the global economy after overcoming the consequences of the corona-economic crisis, taking into account current trends, as well as the principled approaches and perceptions of experts, individual organizations and regional associations.

Key words: pandemic, corona-economic crisis, national economy, benefits of cooperation, competitiveness, economic security.

DOI: 10.51180/RPS.2020.15.2.017.

\section{Author}

Tatul N. Manaseryan

Doctor of Economics, Professor of the Faculty

of Economics and Management

of Yerevan State University

(Yerevan, Armenia)

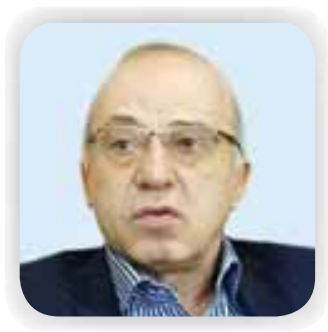

\section{A surprise or a pattern?}

W e tend to believe that the appearance of a new type of virus - COVID-19 can be considered unexpected only from the point of view of medicine and public health. As for the economic consequences and their links to the impending global economic crisis, only those who are far from Economics and economic science can consider it as a surprise.

Even a cursory acquaintance with the development trends in recent years allows us to make realistic forecasts about the future of the world economy. It is enough to get acquainted with the analysis and evaluation of reputable international organizations and rating agencies in order to make an unbiased forecast.
The outbreak of the pandemic only served as a catalyst an accelerated the negative trends that are taking place. After the stages of recovery and growth, the world economy moves to the stage of overproduction and recession, after which we should expect a deep crisis [2].

Excessively intense competition between the main players and centers of power inevitably leads to wasteful, if not wild, exploitation of all possible resources. The global economy is gradually turning into a kind of casino, where the excitement of competing for winnings requires increasing bets and risks. In this case, greater competition on a global scale requires new and new resources, which increases not only the risk, but also threat to the economic security. 


\section{Global economic growth slowdown}

The Organisation for Economic Co-operation and Development (OECD) downgraded its 2020 real GDP growth projections for almost all economies

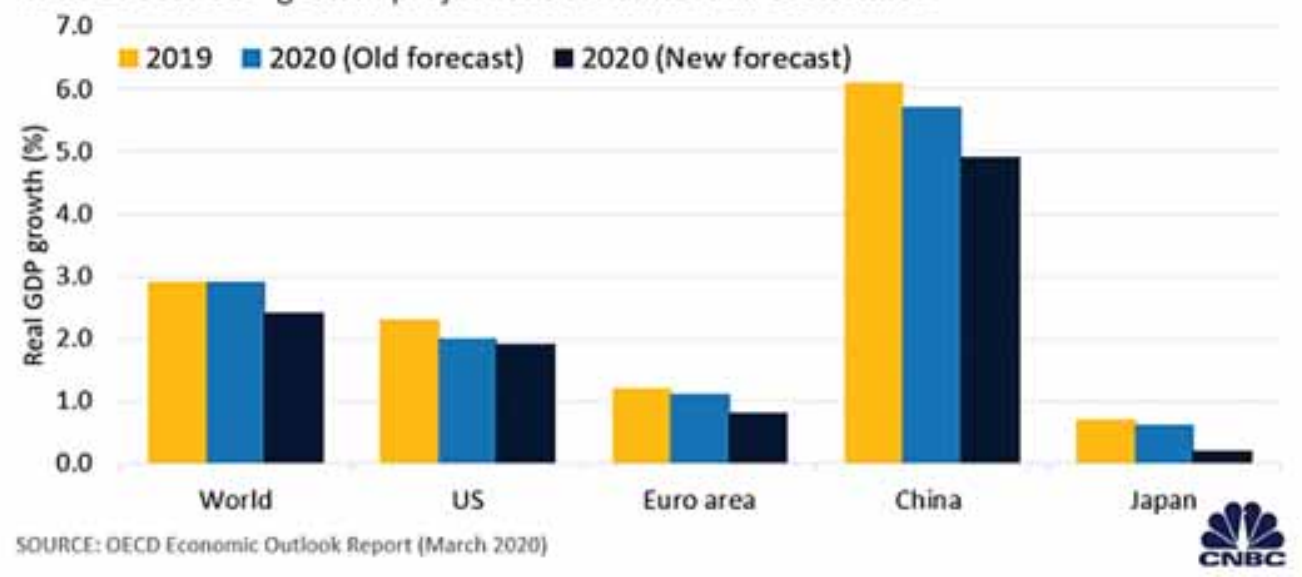

Picture 1. The slowdown in the global economy [1]

Metaphorically speaking, nature hasn't tolerated further violence. Human society uses knowledge of the nature's laws for its barbaric exploitation, which provides it with unprecedented material comfort. But there has to be a price to pay for everything in this life, and humanity pays a high price for killing nature - with its health and life through various infections and diseases. Just read some facts:

- The average passenger car emits as much carbon dioxide per year as it weighs.

- 280 names of harmful substances are contained in vehicle emissions

- 225 thousand people die every year in Europe from diseases related to exhaust gases. Environmentalists and doctors agree: we have at least twice as many victims.

- Every year, 11 million hectares of rainforest disappear from the face of the Earth - this is 10 times the scale of reforestation.

- Half of the Amazon rainforest will disappear by 2030.

- The number of cities that exceed the permissible pollution levels set by the world Health Organization exceeds $50 \%$.
- 36 million Russians live in cities where air pollution is 10 times higher than sanitary standards. $48 \mathrm{~kg}$ of various carcinogenic substances inhaled by the inhabitants of the metropolis.

- The average resident of a megalopolis lives 4 years less than those who live in countryside.

- Number of «millionaire cities»: in the middle of the 19 th century - 4; in 1920 - 25; in 1960 - 140; currently about 300 [3].

It is important to note that not only natural resources, but also other resources are being recklessly and ruthlessly exploited. Human capital or human resources aren't exception. Due to the deterioration of the balance between supply and demand, in particular, of skilled labor, labor migration is increasing every year. At the same time, most of the flows between countries, which consists of unskilled labor (mainly from developing to developed countries) is illegal. It is estimated that about 55,000 migrants are smuggled from East, North and West Africa to Europe each year, bringing criminals about \$150 million. Between 1996 and 2011, at least 1,691 people died trying to cross the 
desert, and in 2008 alone, another 1,000 people died at sea. [4] In 2020 this figure is increasing: under pandemic conditions, clandestine migrants are especially vulnerable, since they are not able to receive legal medical care.

Financial resources are formed, distributed, and used irrationally and disproportionately. Due to the fact that developed countries are increasingly interfering in private business and the economy through huge subsidies, which artificially increases the competitiveness of local production in relation to similar goods and services in developing countries. This, in turn, creates serious barriers to fair competition and enhances social problems, especially increasing the level of poverty in developing countries and in the world as a whole. The number of starving in the poor countries is growing, while every year a huge amount of food is destroyed in developed countries [5].

But because the food system is so fragile, any additional supply cuts or export restrictions can quickly reverse these price trends. Food prices could rise significantly, further weakening global food security. The Food and agriculture organization of the United Nations (FAO) estimates that at least 14.4 million people in 101 countries that are net food importers may suffer from malnutrition Because of the economic crisis triggered by Covid- 19 . And in an extreme scenario (a reduction in the real growth rate of global GDP by ten percentage points in 2020), this figure will increase to 80.3 million [6]. That is why, in the short term, governments must not only provide financial assistance to people and companies affected by the pandemic, but also take action to prevent a food crisis. The authorities should not cut off foreign trade relations, but promote them; they should also improve coordination and information exchange between food producers and consumers, especially at the local level [7].

Production, industrial and technological resources are also distributed inefficiently and disproportionately be- tween countries. Despite the proclaimed principles of free movement of factors of production, in particular, high technologies are not sold even at high prices when they are intended for developing countries. There is a concern that developing countries will become serious competitors to developed countries due to relatively inexpensive labor and new technologies. This fear causes a certain discrimination and further increase in the gap between the levels of economic development of countries in the world economy [8].

Thus, free but not fair competition, discrimination and the barbaric exploitation of natural resources, as well as the extremely uneven distribution of income both within each country and between countries, have led to countries facing a dead end in their search for ways out of the pandemic. By inertia, most countries are trying to find a panacea and minimize the negative consequences of the coronaeconimic crisis as much as possible. It is becoming clear that effective solutions cannot be found alone.

Competition does not exclude cooperation in strategically important areas. In this case, cooperation in the field of overcoming the consequences of the pandemic, in our opinion, has no alternative. Moreover, the benefits of collaboration are incomparable to the risks, assumptions, and likelihood of winning this fight in isolation from others.

\section{The nature, scope and consequences of the crisis}

It is obvious that without trust, it is impossible to imagine yourself in the modern world, especially in terms of conducting an effective fight against coronavirus and other epidemics, as well as many natural and man-made disasters.

As long as the leaders of different countries come to understand the need for close cooperation, the socio-economic crisis is hitting all sides of economic activity hard, thereby increasing social problems on a global scale. 
It is estimated that $\$ 10$ trillion was spent on official support measures around the world. The IMF predicts that global GDP will shrink by an unprecedented $4.9 \%$ in 2020 [9]. At the same time, we believe that there is an urgent responsibility to do the best we can, using the tools at our disposal, to suppress transmission and save lives.

It should be noted that the number of people infected with the virus remains extremely high, in particular, in the developed countries of the world - it is about one quarter of the population, and for some developing countries this figure may be much higher, since it is not calculated accurately.

To develop effective support for the economy, it is important to analyze the sectors that are the engine of development of each economy. Globally, this is primarily tourism, transport services, especially long-haul air transport, hotels, entertainment, leisure and art. At the same time, there are a number of other industries that do not require mass communication of people, therefore, these services not only do not suffer much, but in some cases even thrive. In Armenia, such services include information technology, remote training and education, as well as kinds of business that widely use information technologies and other types of high-tech.

The economic impact of COVID-19 has spread to almost every country, more than two hundred, since it was first diagnosed. This scale and depth of consequences stimulate the growth of threats associated with the global economic crisis. Especially dangerous is the threat of unemployment, the scope of which may be a record for a century.

Without urgent measures to address the social and economic consequences of the COVID-19 pandemic, global problems will escalate, depriving people of their livelihoods for years to come. According to the International labor organization, small businesses, farmers, the self-employed, and refugees will suffer the most. Only in April, 17 million people have lost their jobs. in the United States. France has a high unemployment rate, there the number of unemployed reached 3,732 million people. Between 40 and 60 million people will fall below the extreme poverty line this year, with sub - Saharan Africa the most affected, followed by South Asia. And 265 million people will be on the verge of starvation [10].

The reduction in international trade is estimated by various criteria from $13 \%$ to $32 \%$, which may be more disastrous for countries that are highly dependent on trade.

It's no secret that social consequences are the most important. Social security and protection systems formed and developed over decades sometimes give serious cracks. Health systems in poorer countries were particularly vulnerable. In the US, for example, the unemployment rate jumped to $14.7 \%$ in April, the highest level, and then recovered to $11.1 \%$ in June [11]. The U.S. Bureau of labor statistics report also noted that the percentage of job losses classified as «temporary» fell from $88.6 \%$ in April and may to $78.6 \%$ in June. In other words, a larger percentage of workers stuck at this (still historically high) unemployment rate will not have jobs to return to. This trend is likely to continue, because COVID-19 will force many other companies to close their doors permanently, and governments will not continue to write bailout checks indefinitely [12].

\section{Lessons}

Practice confirms the idea that humanity rarely learns lessons from disasters, which leads to a low level of its security and safety in General. Therefore, it is important to learn from crises. At first glance, the current pandemic does not teach us anything, but there are lessons to be learned from the situation.

The first lesson is not to force nature, but to know it and the laws of its development and make your plans in accordance 
with them. In other words, it is necessary to maintain harmony with nature in everything.

Reflections about your own perception and behavior is also important. After all, while the virus is being researched from a medical point of view, from a socio-economic and political point of view, at first it is necessary to study our perception and behavior in a crisis. The virus shows what many people don't see because of their specialized and isolated mindset: the complexity of our world, our interdependence, and the countless interactions of all spheres-at the moment, for example, between the pandemic and the economy. How a person behaves in a pandemic and how it affects their economic activity [13]. Three years before the current virus spread, the 2017 Nobel prize in Economics was awarded to Richard Thaler, the Professor at the University of Chicago, specifically for research in behavioral Economics ${ }^{1}$, how emotions affect people's economic preferences. After all, Economics as a science works with models - simplified schemes of economic agents (people, households, firms, and so on), in which all their behavior can be described by several equations. One of the most famous such simplifications is that people make economic decisions based on rational rules and goals. The simplified approach allows you to model the behavior of people in a variety of conditions. But the fact is that real people in practice do not always behave rationally. Behavioral Economics studies systematic deviations from rational behavior that are observed over and over again in many people. The same applies to perception: sociologists

\footnotetext{
1 Together with one of his co-authors, lawyer Cass Sunstein, Thaler showed how to "push" people to more rational economic actions, and from this grew not only an interesting book, but also a lot of political decisions. Behavioral Economics was introduced in the United States, the United Kingdom, and more than 50 other countries. The White house has a dedicated team of behavioral economists who are allowed to carefully experiment with government programs. A similar group operates in the UK.
}

and psychologists have identified a number of unproductive behavioral patterns in our handling of disasters: first denial, then fear, then moralizing and scapegoating, and finally action at all costs. Which of these strategies can we see today? How can we replace them with more intelligent behavior? [14]

The second lesson suggests that it is also important to explore the human nature and the factors that influence their decisions, the atmosphere and phenomena that affect their behavior. Therefore, it is necessary to understand how to improve the atmosphere in which a person lives and works, which human qualities should be taken into account when trying to stimulate the effectiveness of their activities or in order to improve their health conditions.

COVID-19 has demonstrated the inconsistency of judgments that in the modern world a person can achieve everything on their own and that many relationships with other people often take up time and do not contribute to their career growth. The pandemic has shown that everyone is vulnerable and dependent on each other, and only our mutual solidarity and attention can save us from many troubles. In fact, humanity is united by a common earthly destiny and responsibility for it.

The pandemic shows that a person has created global problems, but has not reached global agreement with others. In a crisis, the negative consequences of a unipolar world, where the right of the strongest decides everything, are particularly acute. It is obvious that almost all anti-crisis measures were taken at the national level, taking into account the selfish interests of a single state. Many people have the illusion of national self-sufficiency and national superiority. With the exception of the world Health organization, other international structures and mechanisms were not used. Instead, the Americans refused financial payments. Despite the fact that the pandemic affects everyone, it does not affect everyone equally. In many countries, the 
relatively poor are disproportionately ill, and the corona-economic crisis that is now emerging after isolation is hitting developing countries much harder than Western developed countries. As long as many people do not realize the severity of common threats and as long as there are social and psychological imbalances, it is impossible to find effective ways out of the impasse and possible progress. Consequently, the common struggle against global warming and other problems may also may be low-impact.

This leads to the third lesson: global problems require global, universal efforts, which will also help to find acceptable scenarios for human development for all.

It is no secret that global problems are not solved immediately at the global level or only by the efforts of international organizations. Taking into account the fact that the counterbalance to the trend of globalization is regionalization, all acute issues are initially discussed at the regional level, where compromises and opportunities for finding mutually beneficial and realistic solutions are more likely. Therefore, any global problem can be solved rather through regional entities, such as the European Union, the Eurasian Economic Union, the Association Of Southeast Asian Nations, the North American Free Trade zone, etc. As a rule, it is easier to find a common language when the issue is discussed by a few representatives of these regional associations than by the heads of hundreds of national States.

In the current corona-economic crisis, even within developed regional associations such as the EU, the currently more prosperous countries, such as Denmark or Finland, can only hope for sustainable and prosperous development if Spain or Belgium, as well as other severely affected countries, are also well-off. The European Union is going through a huge test during the pandemic, from which it can become stronger or vice versa. While the EU and other regional associations have not passed this test, many countries are in a situation of self-isolation, adhering to the principle of self-salvation. This is confirmed by the lack of mutual support in the struggle against the virus, as well as a clear lack of solidarity to minimize the consequences of the corona-economic crisis.

Herefrom this we can conclude that the fourth lesson is that collective responsibility for the fate of people and the future of States is not only important from the point of view of security and overcoming crisis phenomena, but also very profitable purely economically, as well as for solving many social problems.

For many centuries, the so-called culture of warfare has been developed and improved. Despite numerous negotiations, agreements reached, signed arrangements and other legal acts, and existing regional and international organizations, humanity hasn't learned to live in peace, not to mention the possibility of developing a culture of peace.

The endless arms race, especially the production of weapons of mass destruction and nuclear weapons, deprives humanity of the necessary resources for social progress and the improvement of human well-being. There is an opinion that some live off the other people and off the future generations, including even our own. As a rule, all countries with a growing Arsenal of weapons are also characterized by growing external and internal debt, state budget deficits, and the constant search for additional funds for the production of weapons at the expense of poverty and human health. According to many experts, economic globalization and military expansion are interdependent, but the military component has long been independent. Excessive weapons, especially weapons of mass destruction and nuclear weapons, deprive humanity of the necessary resources for tangible progress and social justice for all, they also pose a threat to security and are the main cause of other crises [15].

Fifth lesson: ensuring food security has a very clear calculation in order to 
eliminate hunger and reduce poverty, while there are no borders to the race for war and military spending, the Solution to this problem is to create and develop a culture of peace. It will help to effectively use the necessary financial and human resources to eliminate the consequences of the pandemic, as well as for other important purposes of ensuring a favorable environment for human life.

There are also other lessons that are important to learn from the current situation. Many experts argue that the largescale spread of the disease, as well as the social and economic consequences of the pandemic, could have been avoided if an adequate response and early warning system had been developed and implemented in each country. In the context of digitalization, this will also help countries minimize losses and undesirable consequences in the event of future crisis situations.

Indeed, most people with COVID-19 will be taken care of at home, and we are learning how to help them there. But the lesson of telehealth - digital medicine - applies not only to the provision of medical services, but also to many other industries. This is part of how each industry will transform as the pandemic accelerates the digitalization of work in each sector. It is necessary to create fair and sustainable models for an optimistic future when humanity emerges from the COVID-19 crisis [16]. The world Economic Forum suggests taking into account the following lessons of crisis management in the era of coronavirus:

- speed and trust;

- broadband Internet access;

- medical reserve capacity. COVID-19 has shown, like the refugee crisis, that the world lacks the capacity to build intensive care facilities;

- ensuring health;

- ethics and justice.

It is important that we understand how much we need an early warning system for future crises, be it climate change or pandemics. Future global crises may arise not only because of diseases-so a warning system like the one proposed by the world health organization Epi - Brain offers a comprehensive model. Having a system that we can trust is crucial: only through trust will citizens act as they did for selfisolation. As telemedicine shows, digital access is now like oxygen [17].

The forum's work on access to spectrum in emergencies is crucial.

COVID-19 has proven that the Internet can support a new era of health care. There is "unaddressed medical care", when modern medicines can be delivered to people's homes [18]. People want to live productively so that they don't have to worry about health care. In India, this is already improving. The prospect of digital medicine is a real product of the Fourth industrial revolution, when artificial intelligence tools are transforming all professions. At the same time, healthcare is the main argument for a hard lesson: the digital future can't just make the rich healthier. Digital medicine gives us an unprecedented opportunity to influence the social determinants of health and provide access to everyone in their area. Eventually, the pandemic can be controlled through drug and vaccine manufacturing technologies, but the lessons we have learned should help us build a powerful future for all people and for all sectors of the economy [19].

\section{Looking to the future: forecasts}

Before predicting the future, it is important to note that the very attitude towards the virus on the part of people, individual government agencies and international organizations is still changing. Recall that even a few weeks after the release of data on the nature and extent of the disease, who was not in a hurry to declare a pandemic. No matter how the pandemic and its economic consequences are treated, according to various estimates and forecasts, the virus will reduce 
Table 1. Main economic forecasts, various estimates (in\% of annual economic growth) [23]

\begin{tabular}{|l|c|c|c|c|c|c|c|c|}
\hline & \multicolumn{2}{|c|}{ World } & Developed countries & Developing countries & \multicolumn{2}{c|}{ USA } \\
\hline & 2020 & 2021 & 2020 & 2021 & 2020 & 2021 & 2020 & 2021 \\
\hline IMF Oct.2019 & $3.4 \%$ & $3.6 \%$ & $1.7 \%$ & $1.6 \%$ & $4.6 \%$ & $4.8 \%$ & $2.1 \%$ & $1.7 \%$ \\
\hline IMF Apr.2019 & $-3.0 \%$ & $5.8 \%$ & $-6.1 \%$ & $4.5 \%$ & $-1.0 \%$ & $6.6 \%$ & $-5.9 \%$ & $4.7 \%$ \\
\hline $\begin{array}{l}\text { IMF } \\
\text { June 2020 }\end{array}$ & $-4.9 \%$ & $5.4 \%$ & $-8.0 \%$ & $4.8 \%$ & $-3.0 \%$ & $5.9 \%$ & $-8.0 \%$ & $4.5 \%$ \\
\hline $\begin{array}{l}\text { OECD } \\
\text { Nov. 2019 }\end{array}$ & $2.9 \%$ & $3.0 \%$ & $1.6 \%$ & $1.7 \%$ & $4.0 \%$ & $4.0 \%$ & $2.0 \%$ & $2.0 \%$ \\
\hline $\begin{array}{l}\text { OECD } \\
\text { March 2019 }\end{array}$ & $2.4 \%$ & $3.3 \%$ & $0,8 \%$ & $1.2 \%$ & $n / a$ & $n / a$ & $1.9 \%$ & $2.1 \%$ \\
\hline $\begin{array}{l}\text { OECD } \\
\text { June 2020 }\end{array}$ & $-6.0 \%$ & $5.2 \%$ & $-7.5 \%$ & $4.8 \%$ & $-4.6 \%$ & $5.6 \%$ & $-7.3 \%$ & $4.1 \%$ \\
\hline $\begin{array}{l}\text { OECD } \\
\text { June 2020 }\end{array}$ & $-7.6 \%$ & $2.8 \%$ & $-9.3 \%$ & $2.2 \%$ & $-6.1 \%$ & $3.2 \%$ & $-8.5 \%$ & $1.9 \%$ \\
\hline World Bank Jan. 2020 & $2.5 \%$ & $2.6 \%$ & $1.4 \%$ & $1.5 \%$ & $4.1 \%$ & $4.3 \%$ & $1.8 \%$ & $1.7 \%$ \\
\hline World Bank June 2020 & $-5.2 \%$ & $4.2 \%$ & $-7.0 \%$ & $3.9 \%$ & $-2.5 \%$ & $4.6 \%$ & $-6.1 \%$ & $4.0 \%$ \\
\hline
\end{tabular}

the volume of world GDP from three to six percent this year only, and in the case of the second wave, this indicator may reach up to ten percent. Until a global strategy to fight the disease is found, it is too early to talk about the stabilization of the world economy and national economies. Even when there is a vaccine, it will not bring the world back to normal. Recovery will occur in fits and starts. We are confident that the development of the global economy after overcoming the consequences of COVID-19 will no longer be similar to the state before the pandemic.

According to the calculations of the world trade organization, the reduction in international trade volumes may amount to $18.5 \%$ per year, and gradually increase in 2021 [20]. Recalling that earlier this organization in April 2020 predicted a reduction in the range of $13-32 \%$. It also reported on G-20 trade measures that between mid-October 2019 and midmay 2020, countries made "significant» progress in facilitating imports, including products related to COVID-19 [21]. Various governments initially responded to the pandemic by introducing new trade restrictions: $90 \%$ were bans on the export of medical products such as surgical masks, gloves, medicines and disinfectants. Since then, the WTO has indicated that G20 economies have lifted $36 \%$ of restrictions and lowered barriers to imports of many pandemic-related products. As of midmay 2020, the WTO reported that 65 of the 93 pandemic-related trade measures implemented during the monitoring period were trade facilitation measures, not trade restrictions [22].

The forecasts presented below reflect different approaches and uncertainty in assessing the possible timing and economic consequences of the corona-economic crisis.

Different forecasts agree that the unemployment rate will remain persistently high over the next few years, while the output-to-GDP ratio will remain low, as both demand and supply have been severely affected in the real economy. Therefore, it takes some time and new game conditions for more dynamic recovery and development. This explains the form of economic recovery similar to the "jagged tick", a form that reflects the gradual process of recovery with a stop and start. 


\section{Jagged Swoosh recovery}

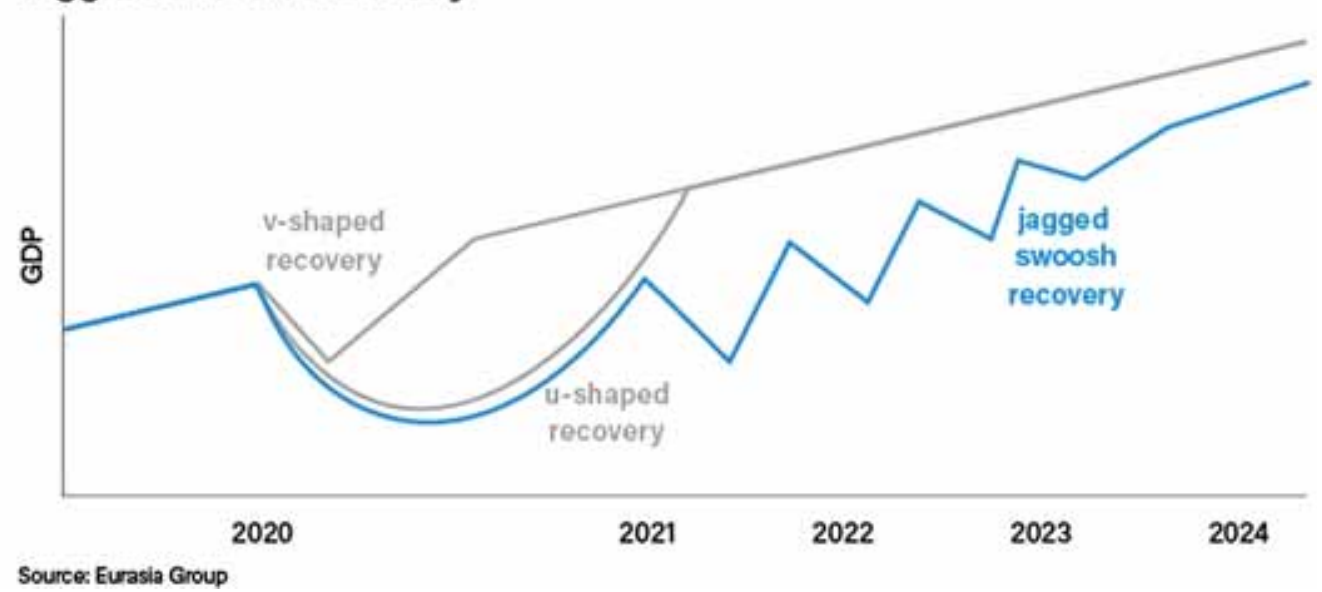

Picture 2. The restoration of the image of the gear tick [24]

There is an assumption that this is just a warning shock. If humanity does not learn to live in peace and harmony, not to force, but to protect nature, then the possibility of a more serious disaster is not excluded. And here no negotiations and new technologies will help. Artificial intelligence cannot take responsibility for the fate of humanity.

From a political standpoint, this means ending the era of the unipolar world that began after the collapse of the Soviet Empire. We need a new security architecture that is based on a multipolar world, which the world's leading powers must move towards consciously and in concert. In the meantime, humanity is not following this path, since there are no signs of real cooperation being required either on a global or even regional scale. The principle of "run for your lives « continues to dominate the modern world. Соoperation and coordination of efforts of States, international and regional organizations are currently idealistic, theoretical, even utopian. This is why the practical significance of the theory of the advantages of cooperation in terms of regional integration is particularly growing. In particular, at the regional level, this improves trade cooperation between neighboring countries. Competitive advantages turn into joint advantages that complement each other's strengths, achieving synergistic results in all possible sectors of the national economy. At the global level, the benefits of cooperation can greatly contribute to peace, stability and comprehensive development.

To represent the potential of regionalization and its potential benefits, it is advisable, in particular, to see the current realities associated with membership of some post-Soviet countries, in particular Armenia, as well as membership of the former socialist countries of Central and Eastern Europe in the EU.

Thus, the identification and implementation of cooperation benefits of cooperation can contribute to the effective search for ways out of the pandemic. The synergistic effect of cooperation and regional integration will also help to unite efforts against many common threats to economic security and bring countries to a qualitatively new level of economic development in the era of digitalization and a new technological revolution.

And finally, the forecasts. In our opinion, it is necessary to develop different scenarios when predicting the future. The optimistic scenario is that trade volumes will quickly recover to pre-pandemic levels in the second half 
of 2020 , or that the global economy is undergoing a V-shaped recovery. On the other hand, under a pessimistic scenario, a partial recovery in international trade is possible, which may continue until 2021: this means that the trend in the development of the world economy is similar to U-shaped growth.

However, according to the new forecast, world trade volumes will not decrease sharply in 2020, but the impact on world trade volumes may exceed the fall in world trade at the height of the financial crisis of 2008-2009 [25].

We assume that scenarios may change depending on possible changes in key factors affecting development trends. In other words, it is important to conduct factor analysis taking into account different trends of parasitism. In any case, development strategy scenarios should be built with the participation of the state, private business, as well as the expert component of civil society.

\section{References}

1. OECD, Economic outlook report, Corona virus: the world economy at risk, March 2020. URL: https://www.oecd.org/economic-outlook/march-2020/

2. Fernandes, Nuno, Economic Effects of Coronavirus Outbreak (COVID-19) on the World Economy (March 22, 2020), pp. 4-13. Available at SSRN: http://dx.doi.org/10.2139/ssrn.3557504

3. Экология: цифры и факты. - URL: http://www.vitamarg.com/eco/article/857

4. Незаконный ввоз мигрантов: суровый поиск лучшей жизни. - URL: https://www.unodc. org/toc/ru/crimes/migrant-smuggling.html

5. Knowles T., Moody R. and McEachern, M.G. European food scares and their impact on EU food policy // British Food Journal. 2007. - Vol. 109. - No. 1, pp. 43-67. — URL: https:// doi.org/10.1108/00070700710718507

6. Маурисио Карденас, Хуан Лукас Рестрепо. Люди рискуют пострадать от голода: как пандемия изменит сельское хозяйство // Forbes. - URL: https://forbes.kz//life/observation/lyudi_riskuyut_postradat_ot_goloda_kak_pandemiya_izmenit_selskoe_hozyaystvo/?

7. Laursen, K., Leone, M. I., Moreira, S., \& Reichstein, T. Exploring the Boomerang Effect: The Role of Core Technologies and Uncertainty in Explaining the Use of the Grant-Back Clause in Technology Licensing// Paper presented at The 35th DRUID Celebration Conference. —2013: Innovation, Strategy and Entrepreneurship, Barcelona, Spain. 2013. — URL: http://druid8. sit.aau.dk/acc_papers/yyqcgffbfp2gm401sevsu9gm8fdp.pdf

8. МВФМВФ ухудшил прогнозы по российской и мировой экономике, June 24,2020 . URL: https://www.dw.com/ru/BA\%D0\%B5/a-53931332

9. Максим Макарычев. ООН: мир ждет исторический уровень безработицы // Российская газета. — 2020. — 28.04. - URL: https://rg.ru/2020/04/28/oon-mir-zhdet-istoricheskijuroven-bezraboticy.html

10. Данные Bureau of Labor Statistics, National Bureau of Economic Statistics, Eurasia Group

11. Congressional Research Service, Global Economic Effects of COVID-19 Updated August 17, 2020, pp. 5-87.

12. Erik Angner (2019) We're all behavioral economists now, Journal of Economic Methodology, 26:3, 195-207, DOI: $10.1080 / 1350178 X .2019 .1625210$

13. Ольга Добровидова, Что такое поведенческая экономика и почему за нее дали Нобелевскую премию, TACC, 9 OKT 2017. — URL: https://tass.ru/ekonomika/4629812

14. Rick Ruddell, Scott H. Decker, Kids and Assault Weapons: Social Problem or Social Construction? May 1, 2005 Research Article. — URL: https://doi.org/10.1177/0734016805275679

15.5 lessons we must take from the coronavirus crisis. - URL: https://www.weforum.org/ agenda/2020/04/5-lessons-from-coronavirus-crisis/

16. International telecommunications union.

17. https://www.statista.com/statistics/617136/digital-population-worldwide/

18. https://www.statista.com/statistics/617136/digital-population-worldwide/

19. Trade Falls Steeply in First Half of 2020, World Trade Organization, June 23, 2020.

20. WTO Report on G20 Shows Moves to Facilitate Imports Even as Trade Restrictions Remain Widespread, World Trade Organization, June 29, 2020. — URL: https://www.wto.org/english/ news_e/news20_e/trdev_29jun20_e.htm. 
21. Report on G20 Trade Measures (Mid-October 2019 to Mid-May 2020), World Trade Organization, June 29, 2020.

22. Разные издания World Economic Outlook, International Monetary Fund; OECD Economic Outlook, Organization for Economic Cooperation and Development; Global Economic Prospects, World Bank.

23. Jan Bremer, The Next Global Depression Is Coming and Optimism Won't Slow It Down, Time, August 6. — URL: https://time.com/5876606/economic-depression-coronavirus/

24. Trade Set to Plunge as COVID-19 Pandemic Upends Global Economy, World Trade Organization, April 8, 2020. — URL: https://www.wto.org/english/news_e/pres20_e/pr855_e.htm.

Translated from Russian into English by Podobueva Veronika, student of RUDN University

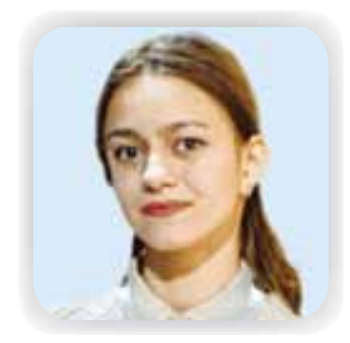

